\title{
Flexural Behavior of Posttensioned Flat Plates Depending on Tendon Layout
}

\author{
Min Sook Kim and Young Hak Lee \\ Department of Architectural Engineering, Kyung Hee University, 1732 Deogyeong-daero, Yongin 17104, Republic of Korea \\ Correspondence should be addressed to Young Hak Lee; leeyh@khu.ac.kr
}

Received 27 April 2016; Accepted 4 July 2016

Academic Editor: Ana S. Guimarães

Copyright ( $) 2016$ M. S. Kim and Y. H. Lee. This is an open access article distributed under the Creative Commons Attribution License, which permits unrestricted use, distribution, and reproduction in any medium, provided the original work is properly cited.

\begin{abstract}
This paper discusses the experimental results on the flexural behavior and deflections of posttensioned concrete flat plates depending on tendon layout. One reinforced concrete flat plate and two posttensioned concrete flat plates were manufactured and tested. One-way posttensioning layout and two-way posttensioning layout were considered in this paper. The load-deflection behavior and modes of crack are presented from the test results. Posttension systems effectively controlled crack and deflection. One-way and two-way posttensioning layouts both showed similar maximum load. However, serviceability improved with two-way posttensioning layout compared to one-way posttensioning layout. Also, the yield-line theory was applied to predict the ultimate load for the posttensioned flat plates. The comparison between the test results and estimation by yield-line analysis generally showed good agreement.
\end{abstract}

\section{Introduction}

Posttensioned concrete flat plate structure has many advantages such as reduction of overall member thickness and simpler construction. Also, these systems have exhibited good performance in terms of ductility and flexural capacity.

The critical failure mode for flat plates is punching shear. Therefore, researchers have studied the way to improve the structural performance of the flat plate through an appropriate tendon layout. Burns and Hemakom [1] performed the test to observe the strength and behavior of posttensioned flat plate. The banded tendon layout was applied in column strip of $x$-direction and single tendons were distributed in $y$ direction of slab. It was found from the experiment that the banded and distributed tendon layout can improve the flexural and shear capacities. The flexural failure demonstrated that the banded tendon layout of column strip resisted the punching shear effectively. Kosut et al. [2] experimentally evaluated the behavior of posttensioned flat plates with distributed and banded tendon arrangement in each direction. They presented that the banded tendon on the column strip can resist the punching shear failure and distributed tendon can improve flexural capacity. Ramos et al. [3] presented the experimental results of flat plates with tendon under punching shear. They showed the results that load capacity decreased as the distance between the tendons and the column increased. For analytical studies, Gilbert et al. [4] proposed automatic yield-line analysis to predict ultimate strength of two-way slabs. Harajli [5] proposed an equation using plastic analysis to calculate the stress in unbonded tendons at ultimate load. They verified the accuracy of the proposed equation in comparison with test data and ACI design code.

Recently, Functionally Graded Materials (FGMs) were developed to improve strength, ductility, and chemical resistance of structural materials. FGMs are a new kind of inhomogeneous composite materials which have low density, excellent chemical resistance, and high stiffness to weight ratio. The application of FGM has been extended to slabs and bridges due to its many advantages. In order to apply FGMs to structural member such as beams and slabs, it is necessary to build a new theory for the beam and the plate. Mahi et al. [6] developed hyperbolic shear deformation theory to predict free vibration frequencies of FGM plates. They showed the accuracy and efficiency of the proposed theory. Belabed et al. [7] presented higher order shear and normal deformation 


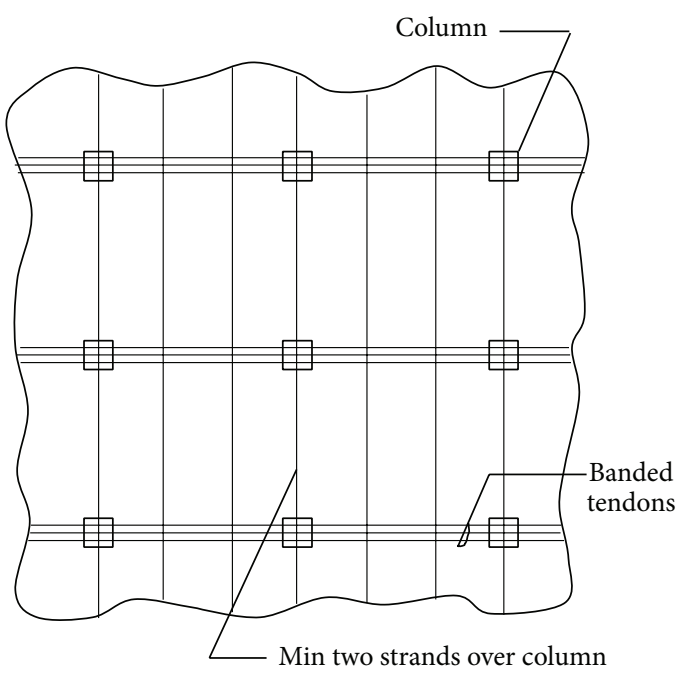

(a) Banded-distributed

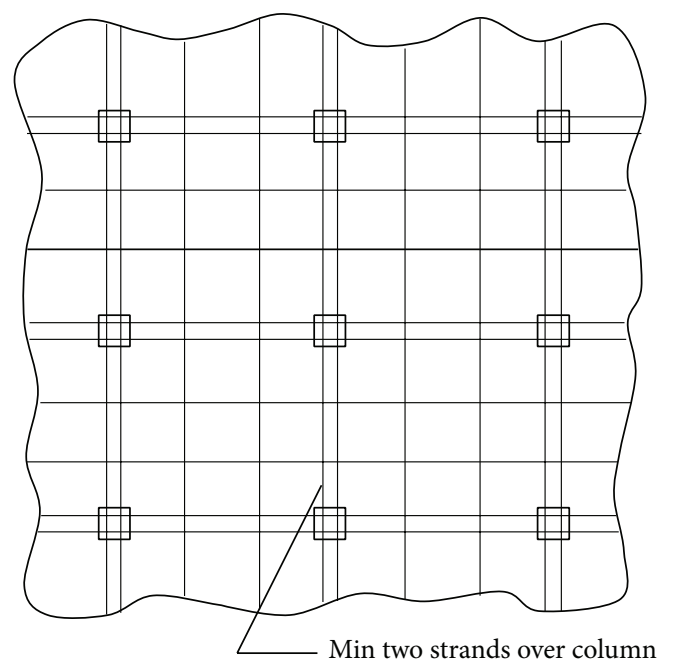

(c) Distributed-distributed

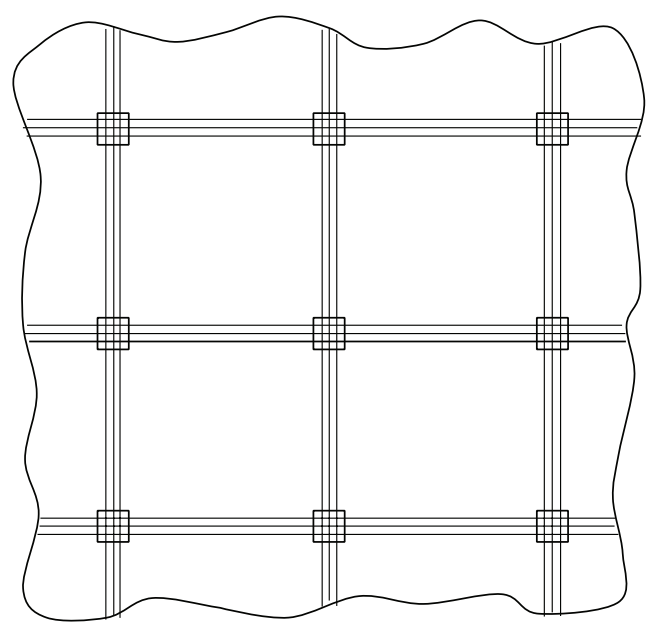

(b) Banded-banded

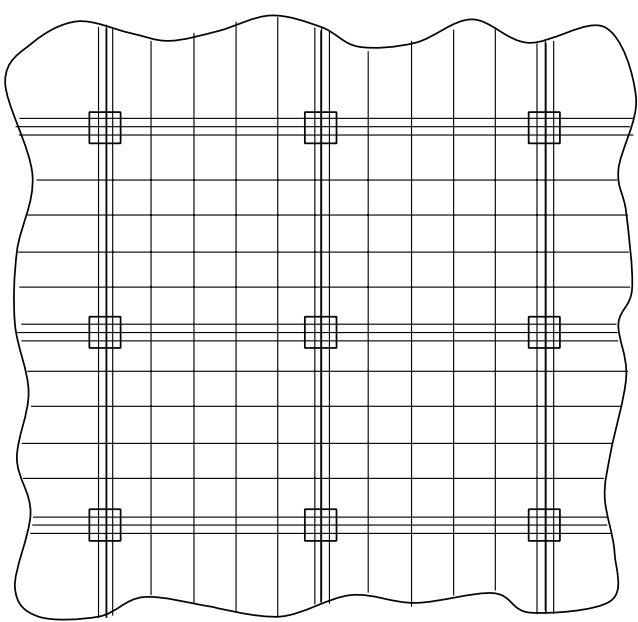

(d) Mixed

FIGURE 1: Principal options of tendon layout [4].

theory for FGM plates. They verified that the theory can consider both shear deformation and thickness stretching effects. Hebali et al. [8] proposed a new quasi-three-dimensional hyperbolic shear deformation theory to analyze the bending and free vibration for FGMS plates.

There are several possible arrangements for the tendon layout in two-way slab system supported by columns [9]. The tendons in each direction can be arranged in combination of banded and distributed layouts as shown in Figure 1. Since the four options provide equal strength capacity, the choice of tendon layout is usually determined by constructability [3].

Posttensioned slabs are used for long spans and heavy live loads where flexural strength and ductility assume a significant role. It is known that the flexural behaviors usually govern the behavior of interior panel in the flat plates. In other words, the distribution of tendons can affect the flexural strength and ductility in the interior panel of the flat plates. Though many researchers have researched into the effect of punching shear to the posttensioned flat plates with various tendon layouts in column strips, most of these researches pointed out that the tendon layouts designs are only presented to prevent punching shear failure. Little information is available on the flexural behavior of posttensioned flat plate. This study aims to recommend the concerning tendon layout design to improve flexural strength and ductility for posttensioned flat plates.

In this study, flexural tests on three concrete flat plate specimens were performed in order to evaluate the flexural behavior and deflection according to the tendon layout. For the comparison purpose, one of three specimens was typical concrete flat plate and the tendons were distributed in one way and in two ways for the other two specimens. Cracking pattern, failure modes, strain, and maximum load were obtained and analyzed from the tests. The test results were also compared to examine the validity of the yield-line theory. 
TABLE 1: Material properties of tendon.

\begin{tabular}{lcccc}
\hline Type & $\begin{array}{c}\text { Diameter } \\
(\mathrm{mm})\end{array}$ & $\begin{array}{c}\text { Area } \\
\left(\mathrm{mm}^{2}\right)\end{array}$ & $\begin{array}{c}\text { Unit } \\
\text { weight } \\
(\mathrm{kg} / \mathrm{km})\end{array}$ & $\begin{array}{c}\text { Elongation } \\
(\%)\end{array}$ \\
\hline SWPC 7B & 12.7 & 98.7 & 774 & 3.5 \\
\hline
\end{tabular}

\section{Experimental Program}

2.1. Materials. The design compressive strength of the concrete used for the fabrication of the specimens was $35 \mathrm{MPa}$. The average compressive strength measured at 28 days was 36.7 MPa. Deformed steel bars with a diameter of $13 \mathrm{~mm}$ and $10 \mathrm{~mm}$ were used as longitudinal reinforcement and stirrups, respectively. And their tensile strength and modulus of elasticity were $400 \mathrm{MPa}$ and $200 \mathrm{GPa}$, respectively. Sevenwire steel strand tendons with $12.7 \mathrm{~mm}$ diameter were used. The nominal ultimate tensile strength of the tendon was $1860 \mathrm{MPa}$. Material properties of the tendons are summarized in Table 1.

2.2. Specimen Details. One concrete flat plate (FR-control) and two posttensioned flat plates were manufactured for the test. For two posttensioned flat plates, one specimen had tendons distributed in only $x$-direction (FR-PT- $x$ ) and the other distributed in both $x$ - and $y$-directions (FR-PT$x y$ ). Details of the specimens are illustrated in Figure 2 and summarized in Table 2. The size of the test specimens was $3000 \mathrm{~mm} \times 3000 \mathrm{~mm}$ and $250 \mathrm{~mm}$ thickness. A minimum concrete cover of $40 \mathrm{~mm}$ was designed for all specimens at compression and tension sides. Two specimens were posttensioned with a constant eccentricity of $43 \mathrm{~mm}$. Since ACI code recommended that the tendon spacing not be greater than eight times the slab thickness [5], the tendons were placed in the middle of the slab at a spacing of $350 \mathrm{~mm}$. Prestressing force of $1488 \mathrm{MPa}$ corresponding to approximately $80 \%$ of the tensile strength of the tendon was applied. A load cell was used to measure the applied jacking load to the tendons during the posttensioning. Minimum bonded deformed longitudinal reinforcement is required in design of prestressed slabs to limit crack width at service load when concrete tensile stresses exceed the modulus of rupture and, for flat plate with unbonded tendons, to ensure flexural performance at ultimate strength $[10,11]$. The minimum amount of bonded deformed longitudinal reinforcement was calculated for the specimens using (1) in positive moment as suggested by ACI 318:

$$
\begin{gathered}
A_{s, \min }=\frac{N_{c}}{0.5 f_{y}}, \\
0.17 \sqrt{f_{c}^{\prime}}<f_{t} \leq 0.5 \sqrt{f_{c}^{\prime}},
\end{gathered}
$$

where $A_{s, \text { min }}$ is a minimum area of bonded deformed longitudinal reinforcement; $N_{c}$ is the resultant tensile force acting on the portion of the concrete cross section that is subjected to tensile stresses due to the combined effects of service loads and effective prestress; $f_{y}$ is a tensile strength of longitudinal reinforcement; $f_{c}^{\prime}$ is compressive strength of concrete; $f_{t}$ is extreme fiber stress in tension in the precompressed tensile zone calculated at service load using gross section properties.

Also, two-way slabs with reinforcement ratios of $1.0 \%$ or more are likely to fail due to a punching shear [12]. For this test, flexural reinforcement ratio of $0.19 \%$ was determined. Each specimen had the same flexural reinforcement ratio in order to secure the equivalent flexural stiffness provided by the longitudinal reinforcement bars. All specimens were reinforced in loading point zone with steel stirrups to prevent punching shear failure that might occur prior to the flexural failure.

2.3. Test Setup. Load was applied to each specimen using a hydraulic jack with maximum capacity of $5000 \mathrm{kN}$. In order to induce the specimens to typical flexural behavior as shown Figure 3, the test specimens were simply supported along the four sides. The force generated by the hydraulic jack was transmitted to a $500 \mathrm{~mm} \times 500 \mathrm{~mm}$ loading plate which was placed at the middle of the specimen as shown in Figure 4. The distance from support to loading point was $1.25 \mathrm{~m}$ to give a shear span to depth ratio of 6 . The magnitude of the loading was measured by a load cell attached to the bottom of the jack. All specimens were loaded until failure to observe the ultimate load-carrying capacity. Nine linear variable displacement transducers (LVDTs) were installed at the bottom of the specimen to measure the vertical displacement, and the strain gauges were attached to the longitudinal reinforcing bars as shown in Figure 4. A data logger was used to collect load, displacement, and strain data.

\section{Test Results}

3.1. Crack Pattern and Deflection. Figure 5 shows the cracks and failure of the specimens. The solid lines represent the experimental crack patterns and the dashed lines represent the theoretical yield-line patterns in the figure. For all specimens, cracks appeared similar to the theoretical yieldline patterns for simply supported four sides of two-way slabs. In the case of the FP specimen, the reinforced concrete flat plate, initial flexural cracks occurred on the bottom surface. And the flexural cracks occurred intensively near the center of the specimen afterward but did not extend outward. After reaching the maximum load, the flexural cracks became wider and some cracks appeared around the edge of the loading plate. The failure occurred at the center of the bottom of the specimen.

In the case of FP-PT- $x$ and FP-PT- $x y$ specimens, the flexural cracks occurred at the center of the specimen. However, unlike the FP specimen, the cracks diagonally propagated towards near the edges of the specimen. FP-PT$x$ and FP-PT- $x y$ specimens showed well distributed flexural cracks compared to FP specimen. As the load increased, some cracks appeared around the edge of the loading plate. Upon reaching the maximum load, flexural cracks became wider and finally failed. However, less number of cracks and smaller crack width were observed in FP-PT- $x y$ than FP-PT$x$ specimen. 

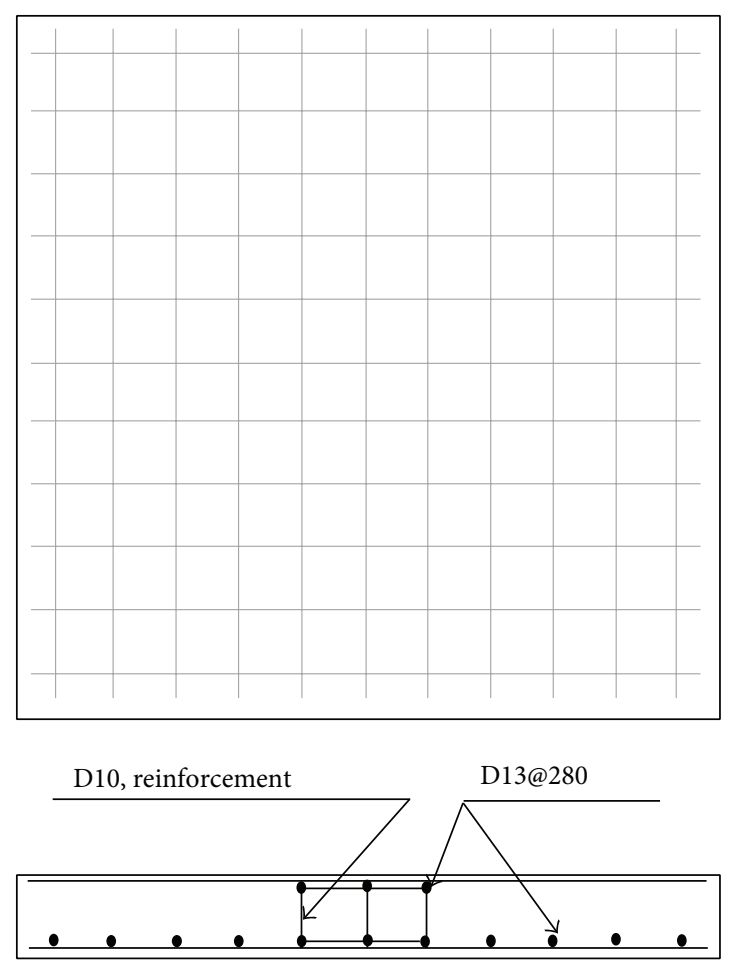

(a) FP-control specimen

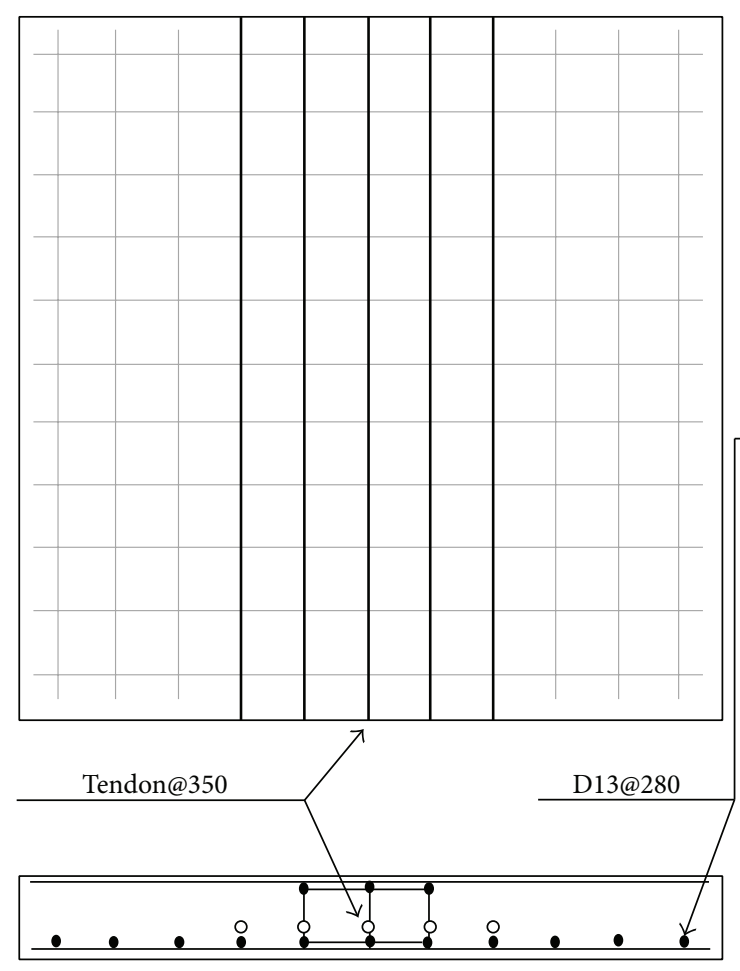

(b) FP-PT- $x$ specimen
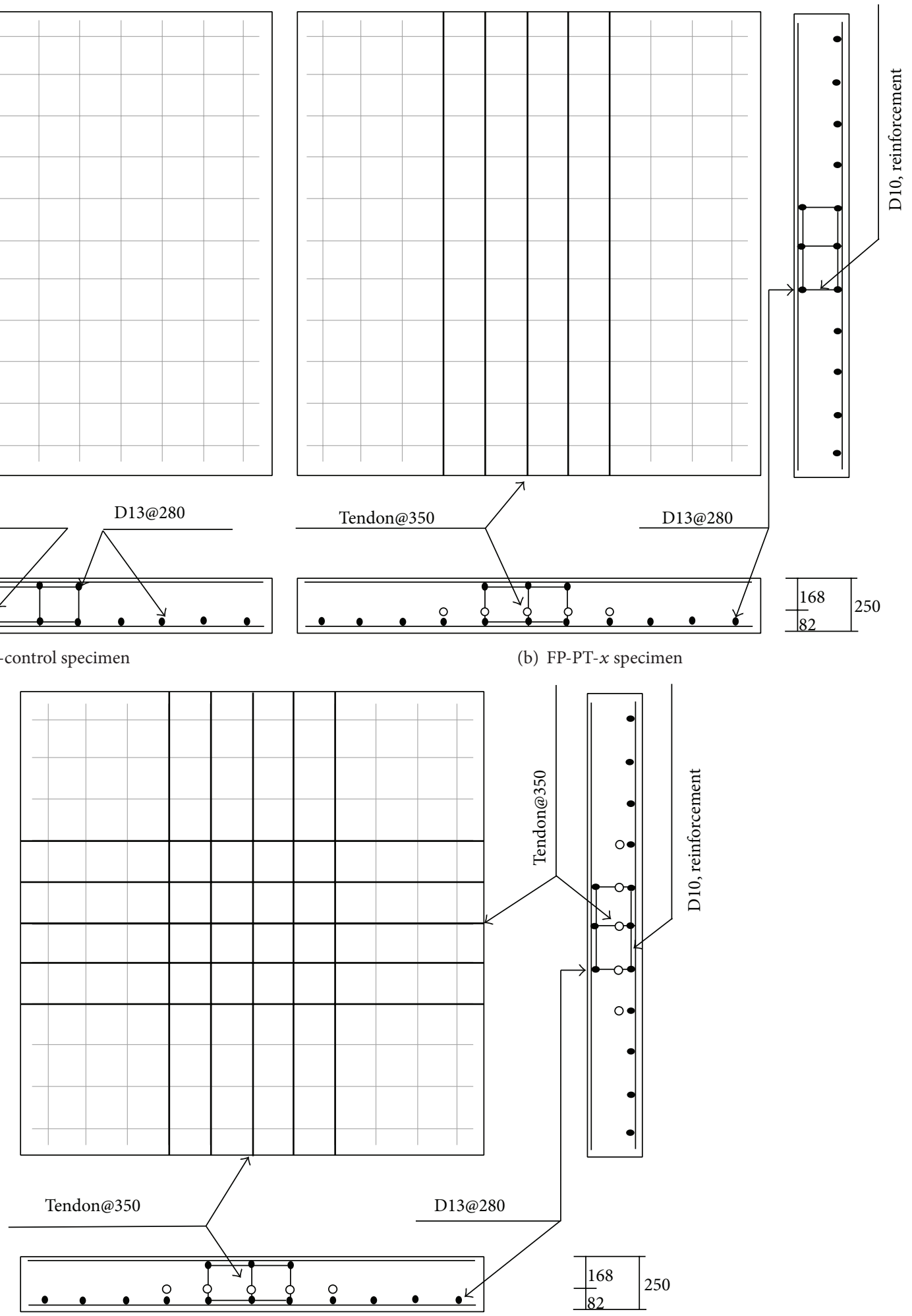

(c) FP-PT- $x y$ specimen

FIGURE 2: Details of the specimens. 
TABLE 2: Details of specimens.

\begin{tabular}{|c|c|c|c|c|c|c|c|c|c|c|}
\hline Specimen & $A_{s, x}\left(\mathrm{~mm}^{2}\right)$ & $A_{s, y}\left(\mathrm{~mm}^{2}\right)$ & $f_{p e}(\mathrm{MPa})$ & $f_{p e} / f_{p u}$ & $\rho_{p, x}(\%)$ & $\rho_{p, y}(\%)$ & $\rho_{s, x}(\%)$ & $\rho_{s, y}(\%)$ & $d_{p}(\mathrm{~mm})$ & $f_{c}^{\prime}(\mathrm{MPa})$ \\
\hline FP-control & - & - & - & - & - & - & 0.185 & 0.185 & - & \\
\hline FP-PT- $x$ & 493.5 & - & 1488 & 0.8 & 0.198 & - & 0.185 & 0.185 & 168 & 36.7 \\
\hline FP-PT- $x y$ & 493.5 & 493.5 & 1488 & 0.8 & 0.198 & 0.198 & 0.185 & 0.185 & 168 & \\
\hline
\end{tabular}

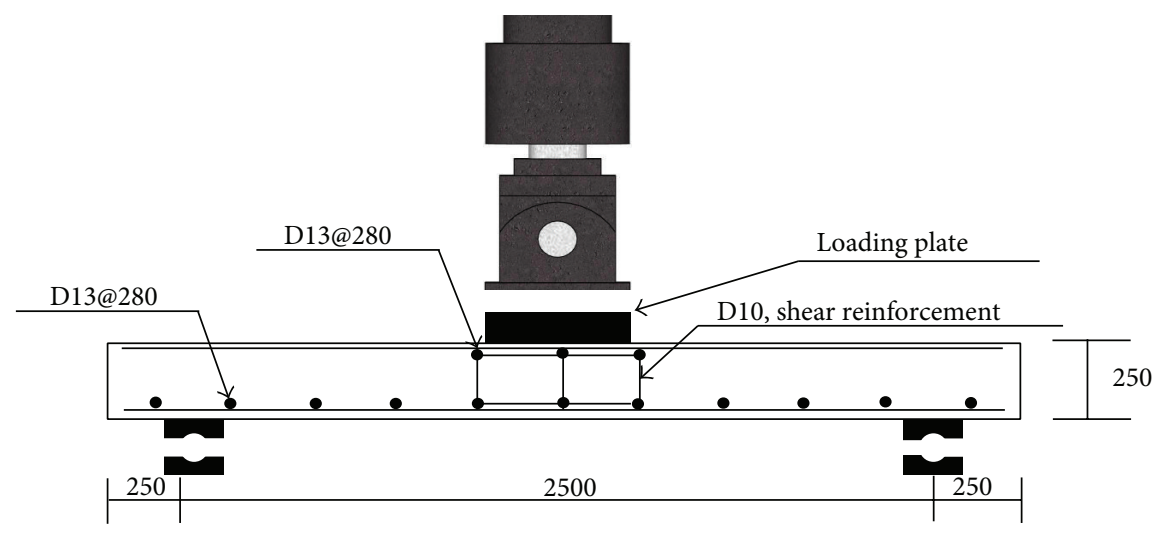

(a)

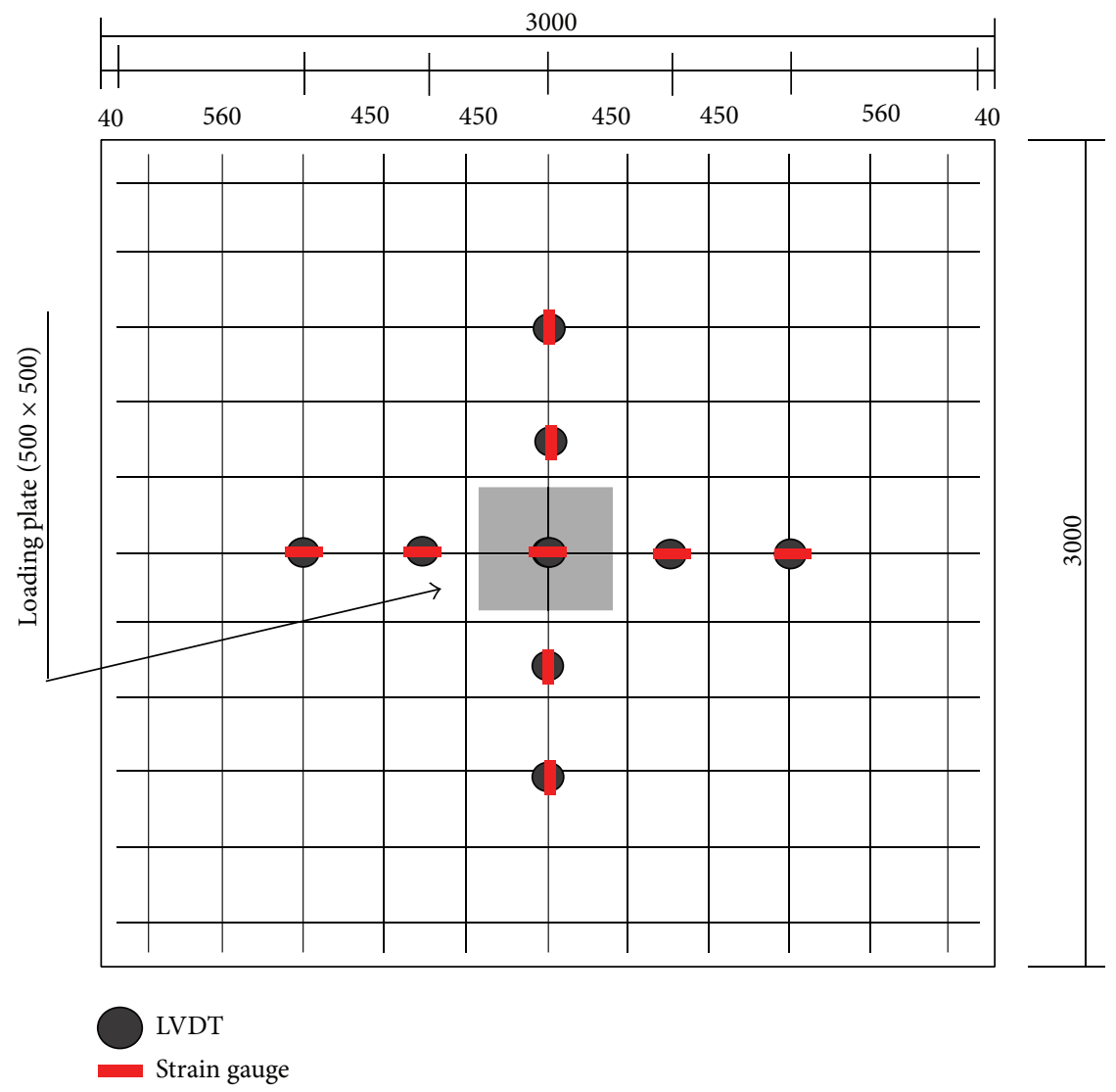

(b)

Figure 3: Test setup. 


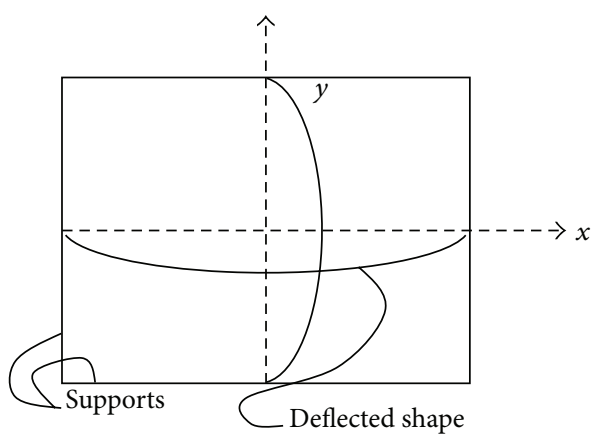

(a) Plan of plate

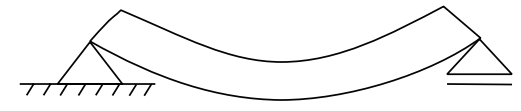

(b) Deflection

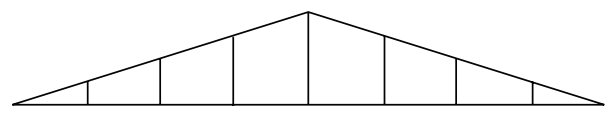

(c) Moment $M_{x}$

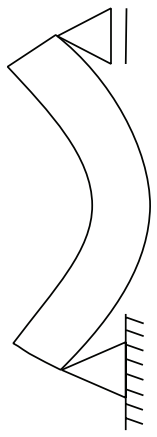

(d) Deflection

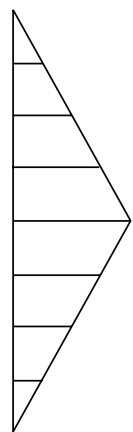

(e) Moment $M_{y}$

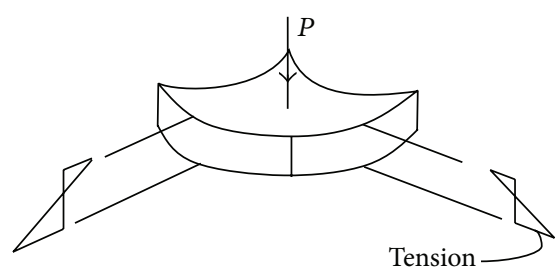

(f) Bending stresses at center

FIGURE 4: Simply supported flat plate under vertical point loading.

The deflection profiles for the specimens are shown in Figure 6 . The deflections obtained at nine locations were analyzed at different loading stages. As shown in the figure, large curvatures before the failure confirm that the failure mechanism of the slabs was governed by flexure rather than shear. In the case of the FP specimen, it was observed that the deflection curve kept almost straight line at a load of $150 \mathrm{kN}$, and the deflection of the center began to increase afterward. The deflection slope became sharper from a load of $450 \mathrm{kN}$. For both FP-PT- $x$ and FP-PT- $x y$ specimens, similar deflection curves were observed, which showed less deflections than the FP specimen. This is because posttensioning contributed to the effective stress distribution.

3.2. Load-Carrying Capacity. The test results for maximum load and deflection are summarized in Table 3 . The maximum load of the FP-control specimen was approximately $520 \mathrm{kN}$, while the maximum loads of FP-PT- $x$ test specimen, a slab in which the tendons were placed in one-way direction, and FP-PT- $x y$ test specimen, a slab in which the tendons were placed in two-way directions, were approximately $718 \mathrm{kN}$ and $757 \mathrm{kN}$, respectively. For FP-PT- $x$ specimen, the maximum load was increased by $38 \%$ compared to the control specimen's, while $45 \%$ increase was observed for FP-PT- $x y$ specimen. The load-displacement relations are shown in Figure 7. The stiffness of all specimens was similar for a load up to $120 \mathrm{kN}$, where the initial flexural cracks occurred. However, the posttensioned specimen showed greater stiffness after the initial cracks. Remarkable differences were not observed in terms of initial stiffness, maximum load, and ductility behavior between FP-PT- $x$ and FP-PT- $x y$. The maximum load of FP-PT- $x y$ specimen, comparing with FP-PT- $x$, was increased by approximately $5 \%$, while the displacement was
TABLE 3: Test results.

\begin{tabular}{lcccc}
\hline Specimen & $P(\mathrm{kN})$ & $\delta(\mathrm{mm})$ & $P_{\mathrm{PT}} / P_{\text {control }}$ & $\delta_{\mathrm{PT}} / \delta_{\text {control }}$ \\
\hline FP-control & 520.22 & 32.24 & - & - \\
FP-PT- $x$ & 718.81 & 40.31 & 1.38 & 1.25 \\
FP-PT- $x y$ & 756.72 & 42.71 & 1.45 & 1.32 \\
\hline
\end{tabular}

reduced by approximately $6 \%$. Although the case of which tendons were placed in two-way directions showed more effective behavior in regard to the crack patterns, the one-way and two-way layouts of tendons did not affect significantly the maximum load capacity and deflection.

The strains were measured at nine points of tension rebars as shown in Figure 3. The load-strain relations are presented in Figure 8. As shown in the figure, from the applied load of $120 \mathrm{kN}$, the strain of rebars of FP-control specimen increased rapidly, while the strain of rebars started increasing dramatically from the applied load of $300 \mathrm{kN}$ for FP-PT- $x$ and from $500 \mathrm{kN}$ for FP-PT- $x y$ because the tension rebar controlled the tensile cracks after the occurrence of the flexural cracks on the concrete for FP-control specimen while the tensile forces applied to the tendons controlled the concrete's tensile cracks for FP-PT specimens.

3.3. Load Capacity Prediction. Yield-line theory is an upper bound solution which depends on pattern of yield lines [13]. It is based on the failure mechanisms in reinforced concrete slabs. The slab is idealized as a rigid body which is connected together by yield lines. At the ultimate load, the total plastic strain energy in the yield lines equated to the external work done by the loads. In this paper, yieldline analysis was performed to predict the ultimate flexural 


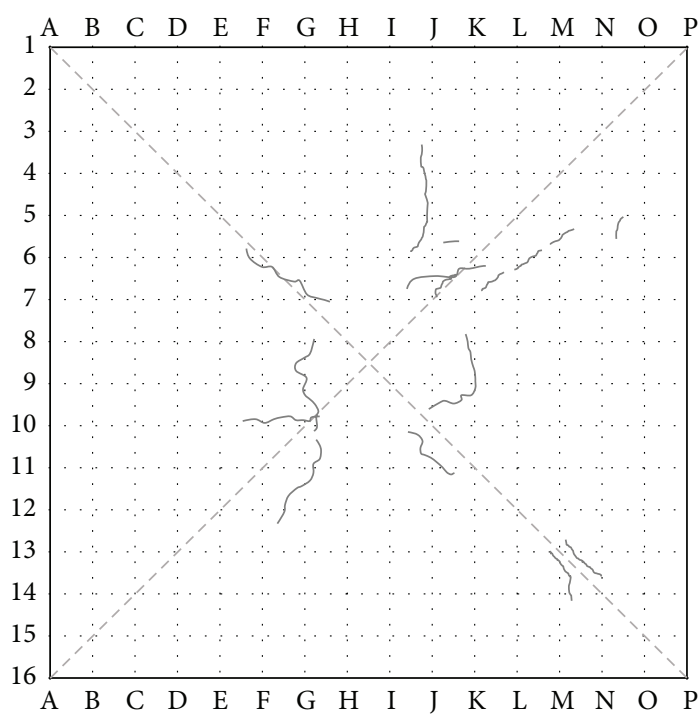

(a) FP-control (top)

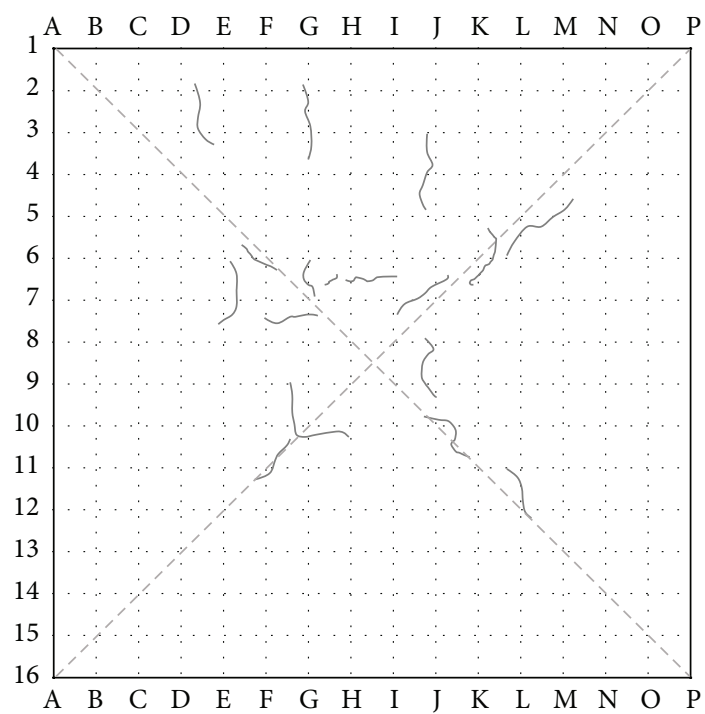

(c) FP-PT- $x$ (top)

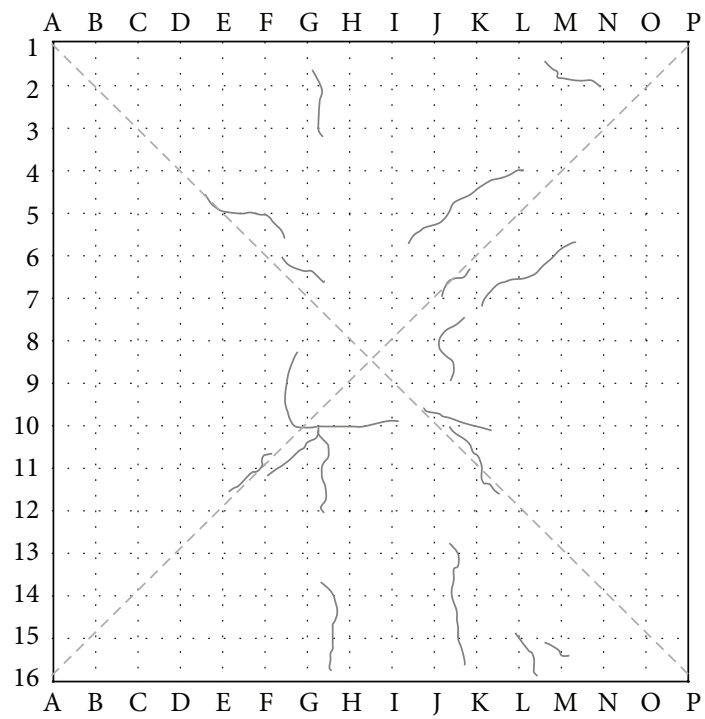

(e) FP-PT- $x y$ (top)

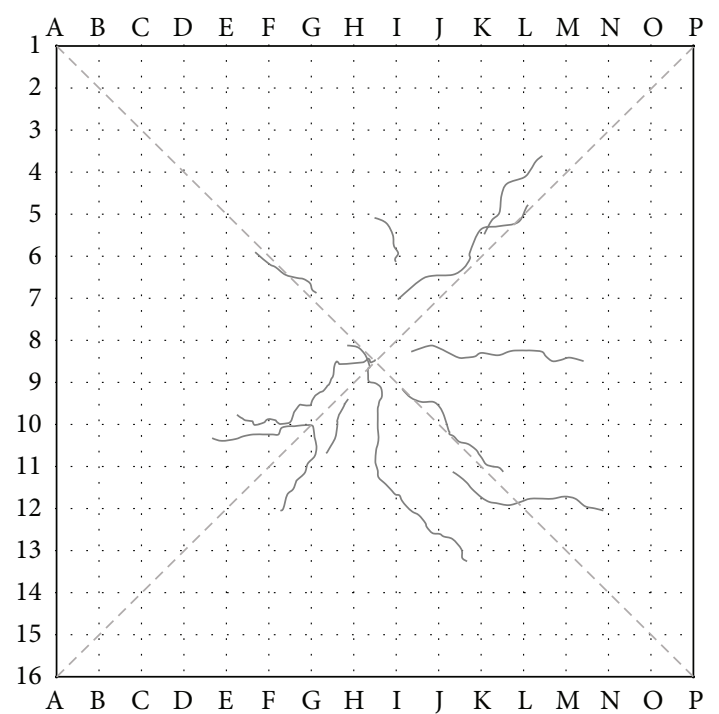

(b) FP-control (bottom)

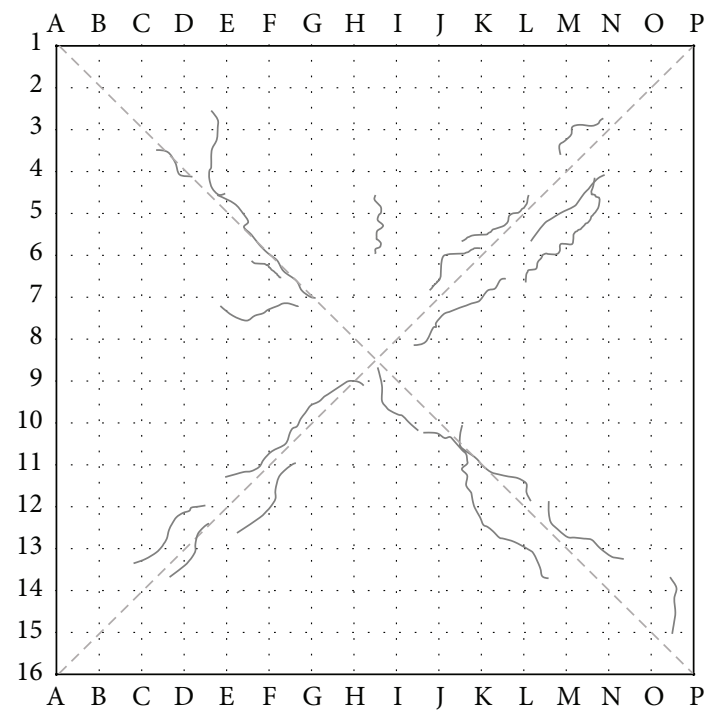

(d) FP-PT- $x$ (bottom)

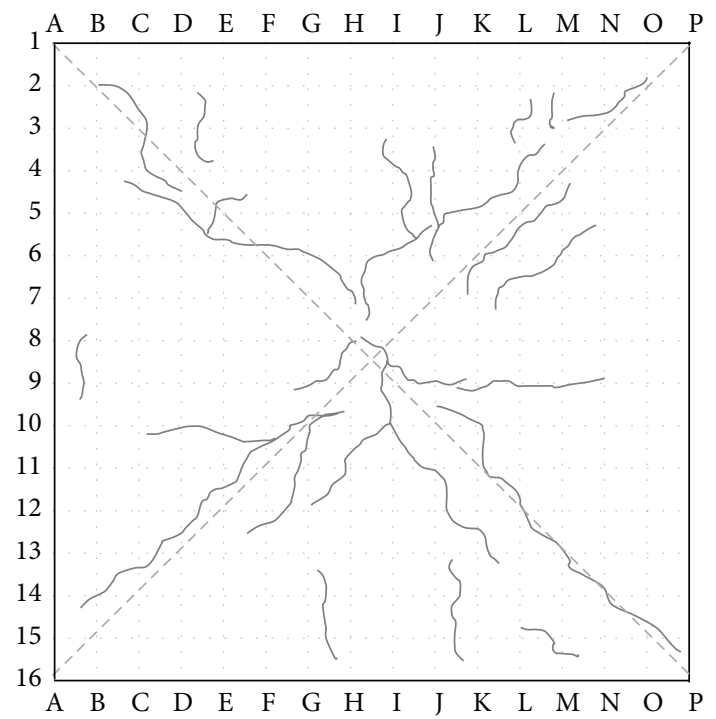

(f) FP-PT- $x y$ (bottom)

Figure 5: Continued. 


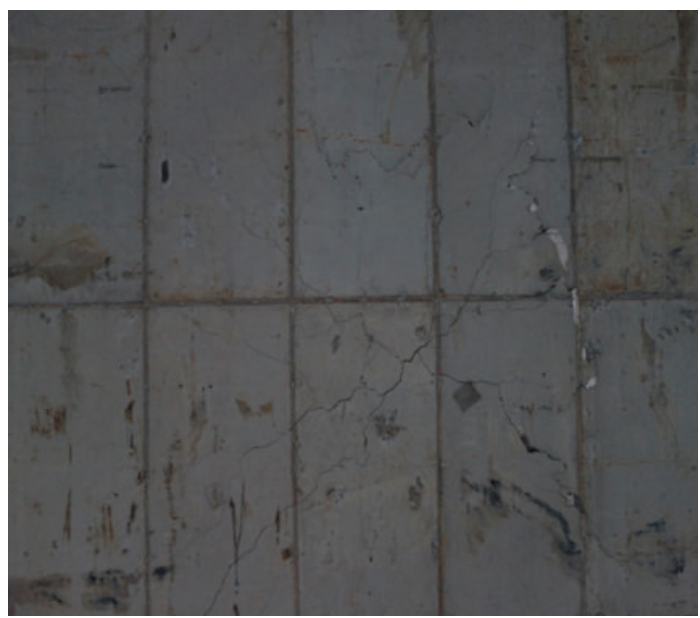

(g) Failure in FP-PT- $x y$ specimen

FIGURE 5: Crack patterns of the specimens.

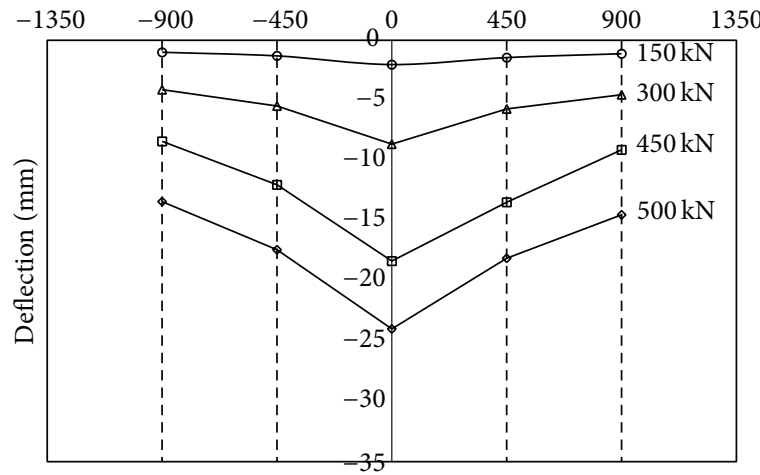

(a) FP-control

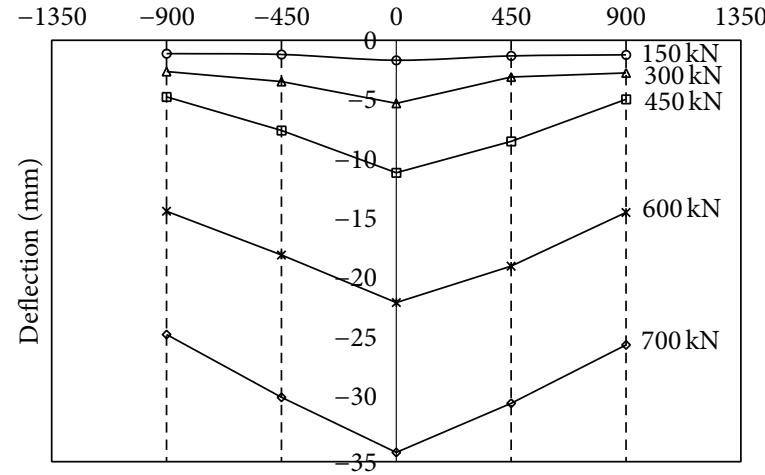

(b) FP-PT- $x$

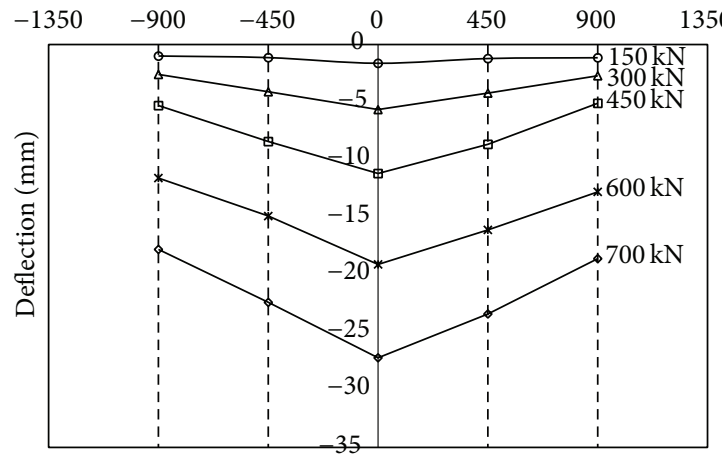

(c) FP-PT- $x y$

FIGURE 6: Deflection profiles of the specimens.

capacity of posttensioned flat plates [2, 14]. Figure 9 presents the failure mechanism and the yield-lines pattern adopted for this study. External work $(E)$ and internal work $(I)$ can be computed from (2) and (3), respectively:

$$
\begin{aligned}
& E=\sum P \delta+\sum \omega_{d} A_{d} \delta_{c}, \\
& I=\sum M_{p x} \theta_{x} l_{y}+\sum M_{p y} \theta_{y} l_{y},
\end{aligned}
$$

where $P$ is failure load; $\delta$ is vertical displacement; $\omega_{d}$ is selfweight of the specimen; $A_{d}$ is area of the failure mechanism; $\theta$ is rotation of the crack line; and $l$ is length of the crack line.

Failure load can be found based on assumption $E=I$. The internal work done by flexure and the external work done by the failure load and self-weight of the slab have been calculated. Table 4 summarizes the result of the failure load analysis using yield-line theory. From the table, it can 


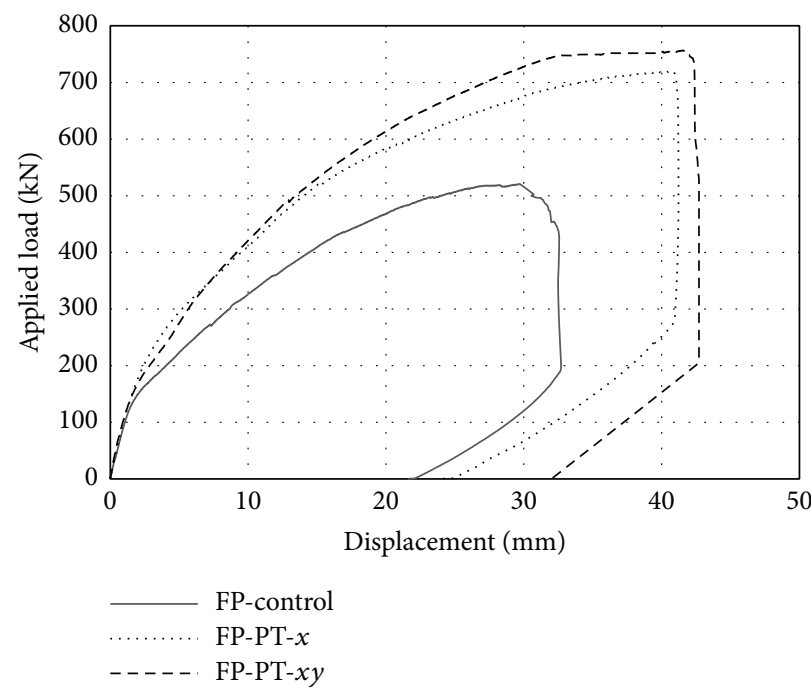

FIGURE 7: Load-displacement relations.

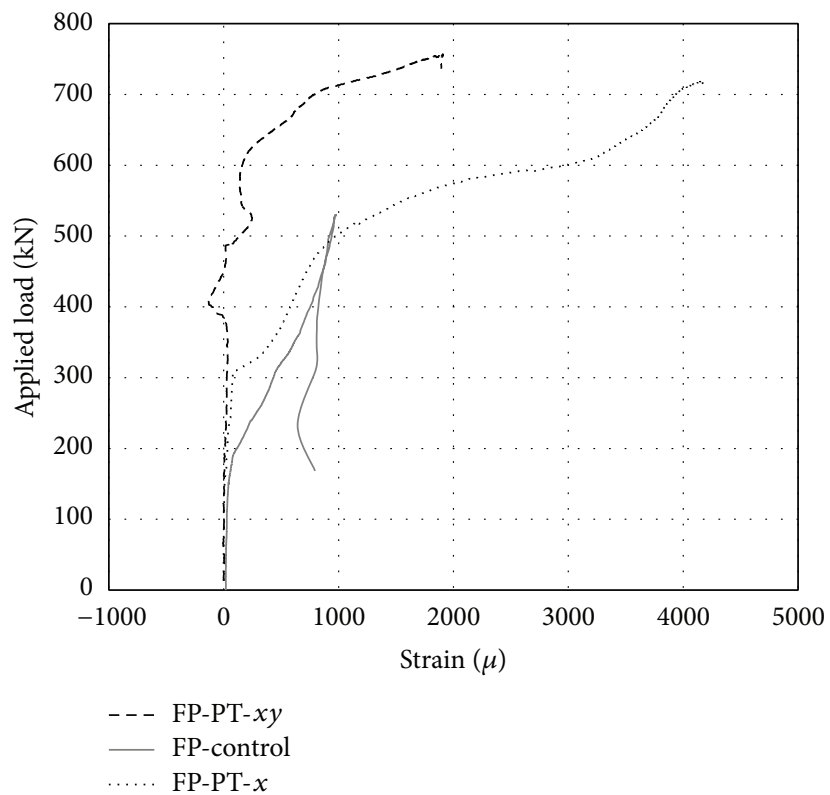

Figure 8: Load-strain relations.

TABLE 4: Results of failure load.

\begin{tabular}{lccc}
\hline Specimen & $P_{\exp }(\mathrm{kN})$ & $P_{\text {cal }}(\mathrm{kN})$ & $P_{\exp } / P_{\text {cal. }}$ \\
\hline FP-control & 520.22 & 504 & 1.03 \\
FP-PT- $x$ & 718.81 & 661 & 1.09 \\
FP-PT- $x y$ & 756.72 & 688 & 1.10 \\
\hline
\end{tabular}

be seen that the calculated failure load of $504 \mathrm{kN}$ is in good agreement with the experimental failure load $520 \mathrm{kN}$ in FPcontrol specimen. However, the yield-line theory tends to relatively underestimate the failure loads for posttensioned specimens. The difference between the experimental results and calculated results is attributed to load carried by membrane action of the slabs.

\section{Conclusions}

In this paper, the behavior of posttensioned concrete flat plates has been investigated experimentally. Flexural tests on three concrete flat plate specimens were performed to examine the effect of the tendon layout type. The cracking patterns, failure modes, strain, and maximum load were analyzed. Test results were compared with the estimations calculated by the yield-line theory. The following conclusions were drawn from this study:

(1) For the posttensioned specimens, the cracks diagonally propagated towards near the edges of the flat plates while the flexural cracks occurred intensively near the center of the typical concrete flat plate. And, for the test specimen where the posttension 


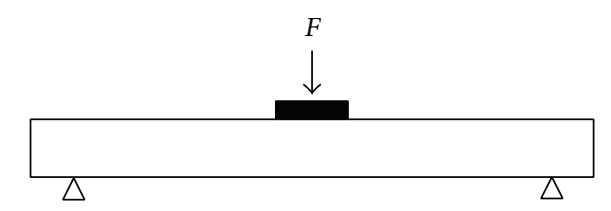

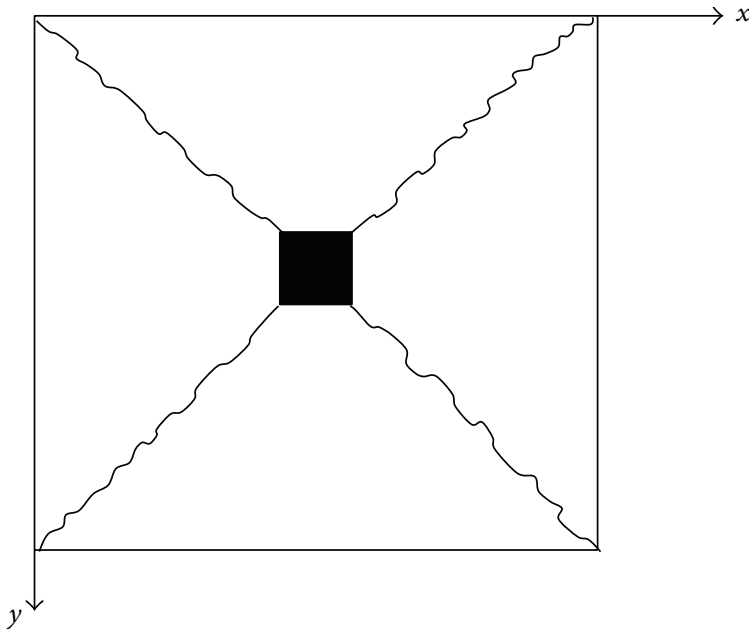

(a) Yield-line pattern

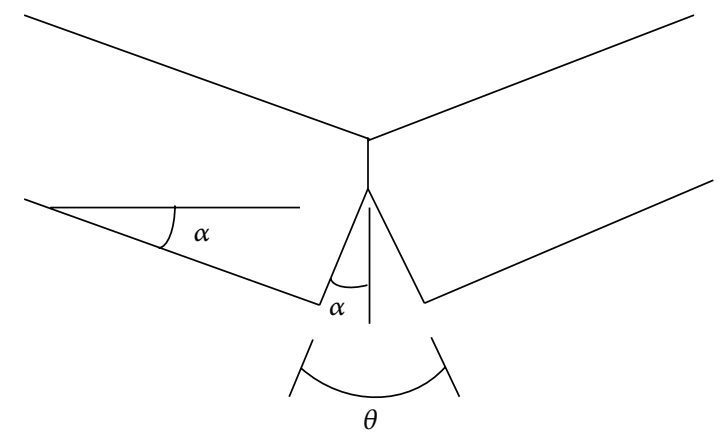

(b) Flexural hinge

Figure 9: Analysis of the slabs.

was not applied, failure occurred at relatively lower load compared with the other two posttensioned specimens' results. The maximum loads for one-way posttensioned and two-way posttensioned specimens increased $38 \%$ and $45 \%$, respectively. Based on these results, the flexural behavior of the flat plate can be improved by the application of posttensioning regardless of the layouts of tendons.

(2) It was found that the increase of the maximum load capacity was not affected by tendon layouts even though the tendons were placed in two directions, since the maximum load and deflection of the specimens, in which the tendons were placed in two-way directions, were greater by $5 \%$ and $6 \%$, respectively, than the one placed in one-way direction. However, the flexural cracks were observed evenly all over the slabs where the tendons were placed in two directions, and several deep cracks were observed in the case of which the tendons were placed in one-way direction compared to those in two-way directions when the crack growth was compared on the surface. Consequently, the placement of tendons in two-way directions is more effective in terms of crack control.

(3) The yield-line theory was applied in order to predict the maximum load of posttensioned flat plates. Comparing with the test results, the calculations by the yield-line theory estimated the maximum loads on average of $93 \%$. However, it tended to relatively underestimate the prediction for the posttensioned slabs because the membrane action resulting from the posttensioning was not considered sufficiently.

\section{Competing Interests}

The authors declare that they have no competing interests.

\section{Acknowledgments}

This work was supported by the National Research Foundation of Korea (NRF) grant funded by the Korean government (MSIP) (NRF-2013R1A2A2A01067754).

\section{References}

[1] N. H. Burns and R. Hemakom, "Test of post-tensioned flat plate with banded tendons," Journal of Structural Engineering, vol. 111, no. 9, pp. 1899-1915, 1985.

[2] G. M. Kosut, N. H. Burns, and C. V. Winter, "Test of four-panel post-tensioned flat plate," Journal of Structural Engineering, vol. 111, no. 9, pp. 1916-1929, 1985.

[3] A. P. Ramos, V. J. G. Lúcio, and D. M. V. Faria, “The effect of the vertical component of prestress forces on the punching strength of flat slabs," Engineering Structures, vol. 76, pp. 90-98, 2014.

[4] M. Gilbert, L. He, C. C. Smith, and C. V. Le, "Automatic yieldline analysis of slabs using discontinuity layout optimization," Proceedings of the Royal Society of London A: Mathematical, Physical and Engineering Sciences, vol. 470, no. 2168, Article ID 20140071, 2014.

[5] M. H. Harajli, "Tendon stress at ultimate in continuous unbonded post-tensioned members: proposed modification of ACI 318, Eq. (18-4) and (18-5)," ACI Structural Journal, vol. 109, no. 2, pp. 183-192, 2012.

[6] A. Mahi, E. A. Adda Bedia, and A. Tounsi, "A new hyperbolic shear deformation theory for bending and free vibration analysis of isotropic, functionally graded, sandwich and laminated 
composite plates," Applied Mathematical Modelling. Simulation and Computation for Engineering and Environmental Systems, vol. 39, no. 9, pp. 2489-2508, 2015.

[7] Z. Belabed, M. S. Ahmed Houari, A. Tounsi, S. R. Mahmoud, and O. Anwar Bég, "An efficient and simple higher order shear and normal deformation theory for functionally graded material (FGM) plates," Composites Part B: Engineering, vol. 60, pp. 274-283, 2014.

[8] H. Hebali, A. Tounsi, M. S. A. Houari, A. Bessaim, and E. A. A. Bedia, "New quasi-3D hyperbolic shear deformation theory for the static and free vibration analysis of functionally graded plates," Journal of Engineering Mechanics, vol. 140, no. 2, pp. 374383, 2014.

[9] B. O. Aalami, "Layout of post-tensioning and passive reinforcement in floor slabs," PTI Technical Note \#8, Post-Tensioning Institute, Phoenix, Ariz, USA, 1999.

[10] ACI Committee 318-14, Building Code Requirements for Reinforced Concrete and Commentary, American Concrete Institute, Farmington Hills, Mich, USA, 2014.

[11] K. B. Bondy, "Two-way post-tensioned slabs with bonded tendons," PTI Journal, vol. 8, no. 2, pp. 43-48, 2012.

[12] H. Marzouk and A. Hussein, "Experimental investigation on the behavior of high-strength concrete slabs," ACI Structural Journal, vol. 88, no. 6, pp. 701-713, 1991.

[13] K. W. Johansen, Yield Line Formulae for Slabs, Cement and Concrete Association, London, UK, 1972.

[14] A. C. Scordelis, T. Y. Lin, and H. R. May, "Shearing strength of prestressed lift slabs," ACI Structural Journal, vol. 55, no. 10, pp. 485-506, 1958. 

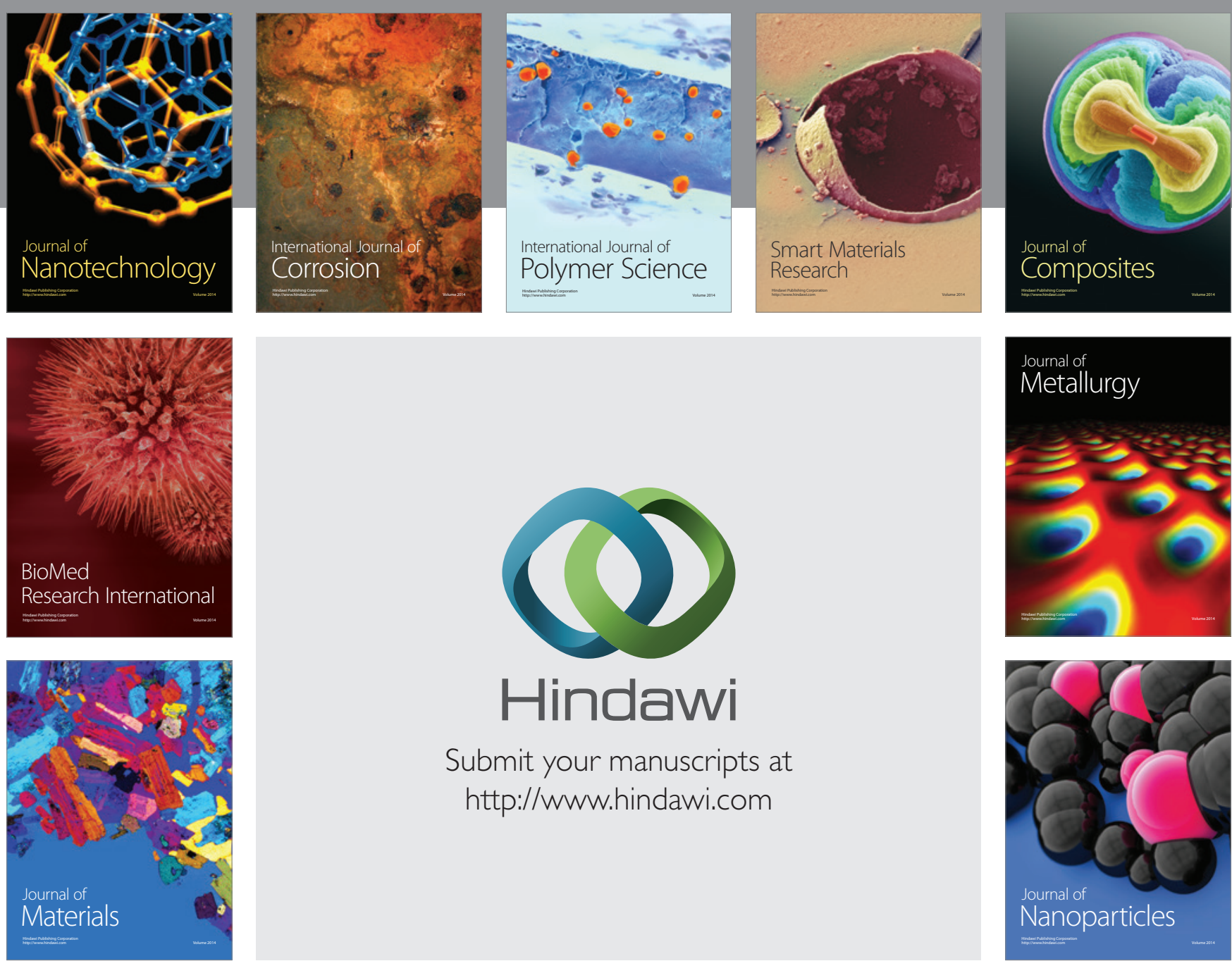

\section{Hindawi}

Submit your manuscripts at

http://www.hindawi.com

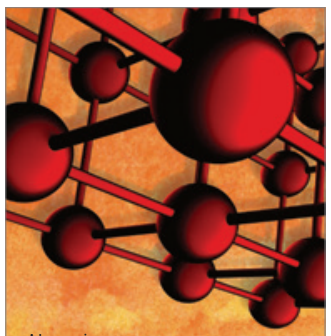

Materials Science and Engineering
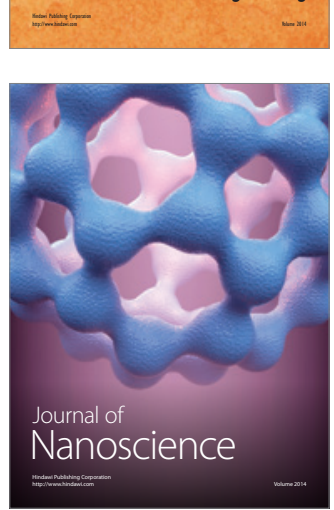
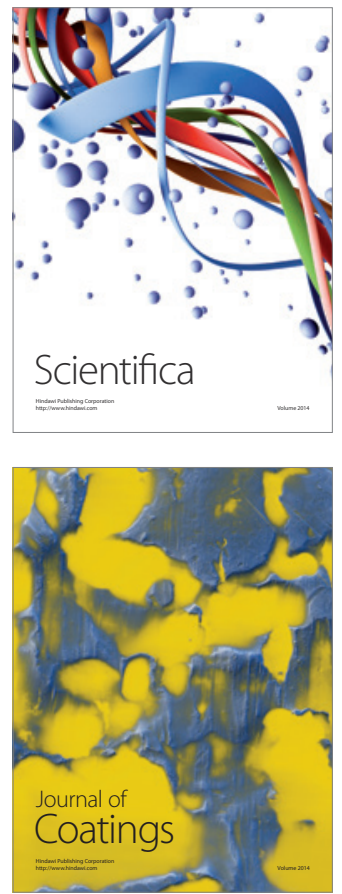
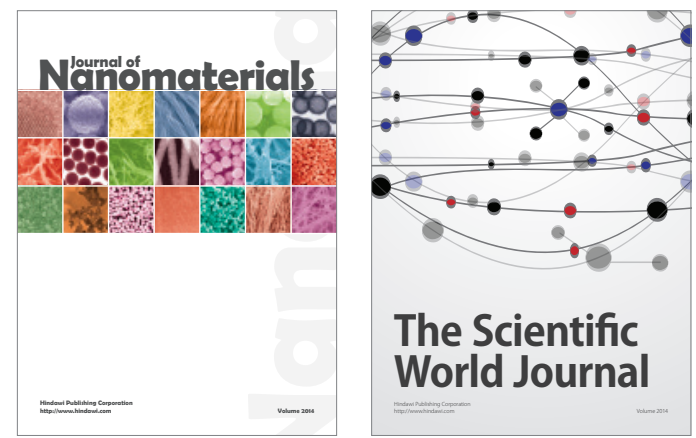

The Scientific World Journal
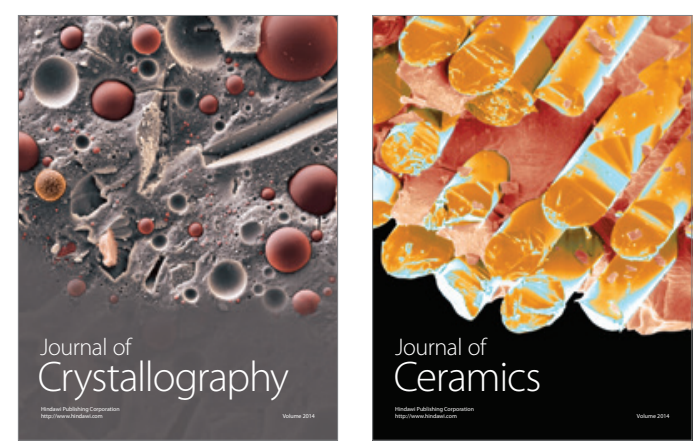
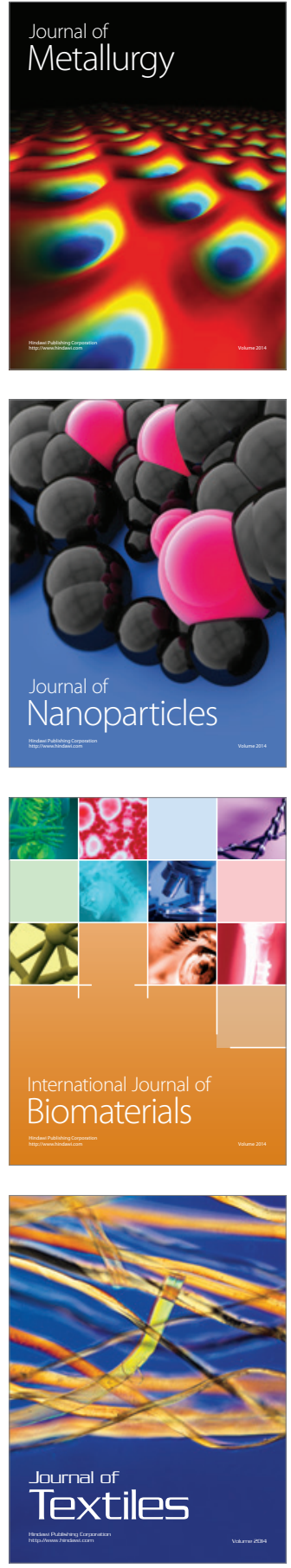